\title{
A META-ANALYSIS OF SELECTED MATERNAL AND FETAL FACTORS FOR PERINATAL MORTALITY
}

\author{
Yifru Berhan", Asres Berhan²
}

\begin{abstract}
BACKGROUND: In several developing countries, achieving Millennium Development Goal 4 is still off track. Multiple maternal and fetal risk factors were inconsistently attributed to the high perinatal mortality in developing countries. However, there was no meta-analysis that assessed the pooled effect of these factors on perinatal mortality. The purpose of this meta-analysis was to identify maternal and fetal factors predicting perinatal mortality.

METHODS: In this meta-analysis, we included 23 studies that assessed perinatal mortality in relation to antenatal care, parity, mode of delivery, gestational age, birth weight and sex of the fetus. A computer based search of articles was conducted mainly in the databases of PUBMED, MEDLINE, HINARI, AJOL, Google Scholar and Cochrane Library. The overall odds ratios (OR) were determined by the random-effect model. Heterogeneity testing and sensitivity analysis were also conducted.

RESULTS: The pooled analysis showed a strong association of perinatal mortality with lack of antenatal care $(O R=3.2)$, prematurity $(O R=7.9)$, low birth weight $(O R=9.6)$, and marginal association with primigravidity $(O R=1.5)$ and male sex $(O R=1.2)$. The regression analysis also showed down-going trend lines of stillbirth and neonatal mortality rates in relation to the proportion of antenatal care. The metaanalysis showed that there was no association between mode of delivery and perinatal mortality.

CONCLUSION: The present meta-analysis indicated a significant reduction in perinatal mortality among women who attended antenatal care, gave birth to term and normal birth weight baby. However, the association of perinatal mortality with parity, mode of delivery and fetal sex needs further investigation.

KEYWORDS: antenatal care, developing countries, meta-analysis, perinatal mortality, skilled person attended delivery
\end{abstract}

DOI: http://dx.doi.org/10.4314/ejhs.v24i1.6S

\section{INTRODUCTION}

The countdown to 2015 decade report (20002010) has shown that child mortality rates have been declining across the globe; however; 49 out of 68 countdown countries are still off track for achieving the millennium development goal 4 (reduce child mortality by two-thirds by achieving a $4.4 \%$ annual rate of decline) primarily due to persistently high perinatal mortality in general and high neonatal mortality in particular (1). It was also pointed out that out of 8.8 million under five child mortality globally, $40 \%$ and $30 \%$ occur during the neonatal and early neonatal periods, respectively $(1,2)$. In other words, in low and middle-income countries, the reduction in neonatal mortality in general and in early neonatal mortality in particular has been slower than the reduction in post neonatal mortality $(3,4)$.

In the majority of low income countries, for every neonatal death, there is another fetal death $(5,6)$. This is because the causes of early neonatal deaths and stillbirths are very closely linked, and

\footnotetext{
${ }^{1}$ Hawassa University, College of Medicine and Health Sciences, Department of Gynecology-Obstetrics

${ }^{2}$ Hawassa University, College of Medicine and Health Sciences, Department of Pharmacology

Corresponding Author: Yifru Berhan, Email: yifrub@yahoo.com
} 
are usually obstetric in origin and strongly associated with causes of maternal mortality and morbidity $(7,8)$. As a result, assessing the association of perinatal deaths with potential obstetric and related factors can help identify the highest risk factors, and is used as an indirect measurement of the availability and quality of care provided to pregnant women and neonates in a given society $(9,10)$.

Risk factors for perinatal mortality are multiple. Several studies have shown a strong association of perinatal mortality with asphyxia, preterm delivery, neonatal infections, infection during pregnancy and maternal anemia (11-15). In the interest of this meta-analysis, the review of other studies on the association of perinatal mortality with some of the other obstetric risk factors (antenatal care and mode of delivery) has shown inconsistent results; some demonstrated that antenatal care was not associated with a reduction in perinatal mortality (16-18), and some others have shown a marked reduction in perinatal mortality (19-25). In another study, not included in this analysis, it was noted that women who lost their babies during the perinatal period were less likely to receive prenatal care, and babies were less likely to be delivered by cesarean section, but more likely to be delivered as breech (26). Furthermore, the association of perinatal mortality with parity and the sex of the baby was not clear.

However, there was no meta-analysis that assessed the pool effect of the findings of individual studies on the overall perinatal mortality. The purpose of this meta-analysis was to identify maternal and fetal factors predicting perinatal mortality.

\section{METHODS}

\section{Search strategy}

A Computer based literature search was conducted mainly in the databases of African Journals Online, Google scholar, HINARI, PUBMED, Medline and the Cochrane Library. Using HINARI, the websites of major publishers (Elsevier Science-Science Direct, Nature Publishing Group, Oxford University Press, PsycARTICLES, Science and Wiley-Blackwell) were also searched. The literature search was further strengthened by searching the reference lists of retrieved articles. The following search terms were used: perinatal mortality, antenatal care, mode of delivery, vaginal delivery, cesarean delivery, skilled person unattended delivery, gestational age, term, preterm, parity, primigravida, multiparous, fetal sex and weight. The selected search terms were combined alternatively using the Boolean logic (AND, OR \& NOT).

\section{Inclusion criteria and study selection}

The predetermined inclusion criteria were studies that assessed perinatal mortality in developing countries in relation to obstetric factors, written in English and published after the year 1990. The study selection process was conducted in two phases by both authors independently. In the first phase, titles and abstracts of all the retrieved articles were reviewed and then grouped as "eligible for full document review" and "ineligible for full document review". In the second phase, the full document of all the articles grouped as "eligible for full document review" were reviewed in detail and grouped as "eligible for metaanalysis" and "ineligible for meta-analysis". In the case of discrepancy in the grouping of articles, inclusion or exclusion of the disputed articles was resolved by discussion and by reviewing the articles together. The selected studies were observational (a mix of retrospective, prospective and cross sectional) by design, and a mix of community based and hospital based by sites. The outcome measure in all included studies was perinatal mortality.

\section{Data extraction}

Using Excel spreadsheet, data extraction was conducted by both authors using the same data extraction template. During data extraction, the following issues were abstracted: antenatal care, mode of delivery, skilled person unattended delivery, gestational age, parity, fetal sex and weight. All the extracted data were transferred to the meta-analysis software (Review Manager).

\section{Statistical analysis}

Since the software could not analyze trichotomous and above variables, stratified data were purposely grouped as: antenatal care (yes/no), primigravida/multigravida, fetal gestational age 
(term/preterm), fetal birth weight $(<2500 \mathrm{gm} />=$ $2500 \mathrm{gm})$ and fetal sex (male/female).

Since a very significant variability was observed in the fixed effects model (60\%-99\%), perinatal mortality in relation to selected obstetric factors was evaluated using the random effects model. Odds ratios (OR) and $95 \%$ confidence intervals $(95 \% \mathrm{CI})$ for the selected variables were computed with the Mantel-Haenszel (MH) method. When the $95 \%$ CI did not contain number 1 , it was considered as statistically significant. In each forest plot, the length of the horizontal lines indicates the width of the $95 \%$ CI (the wider the $\mathrm{CI}$, the less the confidence level) and the size of each square on the horizontal line represents the weight of the sample size.

The consistency of the included studies was assessed by heterogeneity testing using $\mathrm{I}^{2}$ statistics. When the value of $\mathrm{I}^{2}$ was greater than or equal to $50 \%$, it was considered that the heterogeneity is statistically significant. When there was a significant heterogeneity among the studies, sensitivity analysis (leave one study out a time analysis) was performed to see the stability of the overall OR to outliers and the change in $\mathrm{I}^{2}$. All the analyses were conducted with Review Manager (RevMan) Version 5.1 software. The bivariate Pearson correlation coefficient was determined using SPSS software to assess the correlation of antenatal care with stillbirths and early neonatal deaths.

\section{RESULTS}

\section{Description of the studies}

As shown in Figure 1, 1211 literatures were initially accessed for the selected search terms. Of these, 134 were retrieved; 73 were excluded after reviewing the abstracts. Sixty one articles were reviewed in detail and nearly two-thirds were excluded because of the non-comparative nature of the studies; differences in the definition of gestational age of fetal viability and neonatal period; qualitative design or reviews and audits and variation in the interest of assessed variables. Finally, 23 studies (between 1995 and 2011) were selected for this meta-analysis (16-25, 27-39).

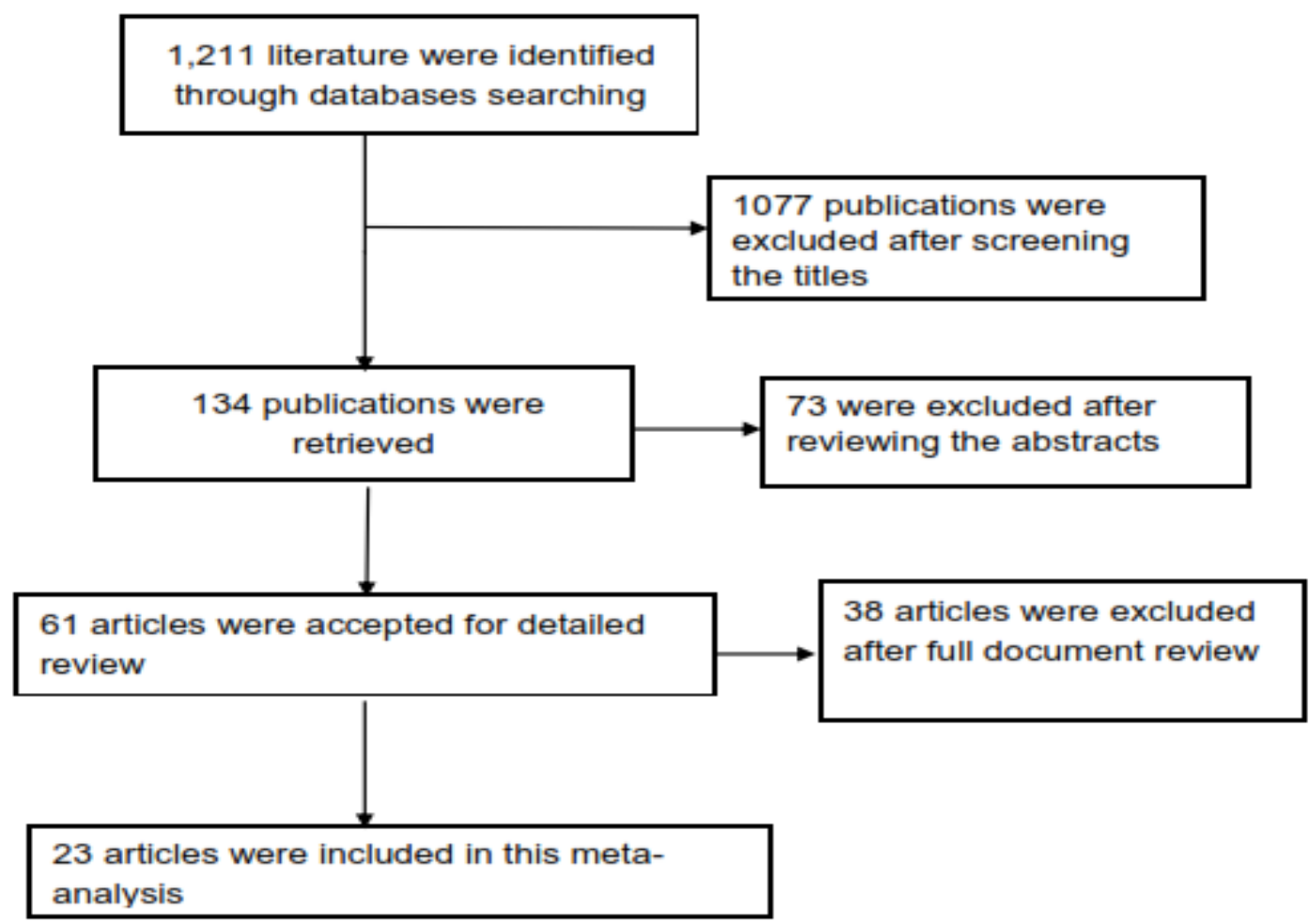

Figure 1: Flow diagram showing studies selection for this meta-analysis 
As shown in Table 1, of the included studies, 18 were from Sub-Saharan Africa (16-21, 23-25, 27 $29,31,33-35,38,39$ ); the remaining were, one each, from Brazil, Afghanistan, Thailand and Bangladesh $(22,30,32,36)$; and one was a multicounty study (37). Twenty studies were published between 2006 and 2013. Twelve studies were community based, and the remaining eleven studies were health facility based. The study designs of the included articles were prospective cohort (\#14), retrospective analysis (\#6) and cross sectional (\#3).

Table 1: General characteristics of the included small scale studies

\begin{tabular}{|c|c|c|c|c|c|}
\hline Authors & $\begin{array}{l}\text { Year of } \\
\text { publicati } \\
\text { on }\end{array}$ & Study period & Location & Data source & Study design \\
\hline $\begin{array}{l}\text { Engmann } \mathrm{C} \text { et al } \\
\text { (16) }\end{array}$ & 2011 & 2002 to 2008 & Ghana & Community based & Prospective cohort \\
\hline $\begin{array}{l}\text { Fawole } \mathrm{AO} \text { et al } \\
\text { (17) }\end{array}$ & 2011 & $\begin{array}{ll}\text { October } 2004 & \text { to } \\
\text { February } 2005 & \end{array}$ & Nigeria & Hospital based & $\begin{array}{ll}\text { Cross } & \text { sectional } \\
\text { study } & \end{array}$ \\
\hline $\begin{array}{l}\text { Nankabirwa V et al } \\
\text { (18) }\end{array}$ & 2011 & $\begin{array}{l}\text { January } 2006 \text { to May } \\
2008\end{array}$ & Uganda & Community based & Prospective cohort \\
\hline Diallo et al (19) & 2010 & June 2006 to May 2007 & Burkina Faso & Community based & Prospective cohort \\
\hline Ekure EN et al (20) & 2011 & $\begin{array}{l}\text { June } 2002 \text { to November } \\
2002\end{array}$ & Nigeria & Hospital based & Prospective cohort \\
\hline $\begin{array}{l}\text { Matendo RM et al } \\
\text { S1 (21) }\end{array}$ & 2011 & June-December 2005 & $\begin{array}{l}\text { D. Republic } \\
\text { Congo }\end{array}$ & Community based & Prospective cohort \\
\hline $\begin{array}{l}\text { Mo-suwan L et al } \\
(22)\end{array}$ & 2009 & 2000 to 2002 & Thailand & Community based & Prospective cohort \\
\hline $\begin{array}{l}\text { Olatinwo A et al } \\
\text { (23) }\end{array}$ & 2000 & $\begin{array}{lll}\text { January } & 1996 & \text { to } \\
\text { December } & 1998 & \end{array}$ & Nigeria & Hospital based & Retrospective study \\
\hline Ibkwe PC et al (24) & 2011 & $\begin{array}{lcl}\text { January } & 2004 & - \\
\text { December } & 2005\end{array}$ & Nigeria & Hospital based & $\begin{array}{l}\text { Retrospective } \\
\text { analysis }\end{array}$ \\
\hline Kuti O et al (25) & 2003 & $\begin{array}{lcl}\text { January } & 1996 & - \\
\text { December } & 2000\end{array}$ & Nigeria & Hospital based & $\begin{array}{l}\text { Retrospective } \\
\text { analysis }\end{array}$ \\
\hline $\begin{array}{l}\text { Abu Habib NA et al } \\
\text { (27) }\end{array}$ & 2011 & 1999 to 2006 & Tanzania & Hospital based & Prospective cohort \\
\hline $\begin{array}{l}\text { Andargie } \mathrm{G} \text { et al } \\
(28)\end{array}$ & 2013 & $\begin{array}{l}\text { November } 2009 \text { to } \\
\text { August } 2011\end{array}$ & Ethiopia & Community based & Prospective cohort \\
\hline $\begin{array}{l}\text { Hinderaker SG et al } \\
(29)\end{array}$ & 2003 & $\begin{array}{l}\text { January } 1995 \text { to March } \\
1996\end{array}$ & Tanzania & Hospital based & Prospective cohort \\
\hline Lansky S et al (30) & 2007 & 1999 & Brazil & Hospital based & Prospective cohort \\
\hline Oti SO et al (31) & 2011 & 2003 & Nigeria & Community based & Cross sectional \\
\hline Pervin J et al (32) & 2012 & 2005 to 2009 & Bangladesh & Community based & Prospective cohort \\
\hline $\begin{array}{l}\text { Bjerregaard- } \\
\text { Andersen et al (33) }\end{array}$ & 2012 & $\begin{array}{l}\text { September } 2009 \text { to } \\
\text { August } 2011\end{array}$ & $\begin{array}{l}\text { Guinea- } \\
\text { Bissau }\end{array}$ & Community based & Cohort \\
\hline $\begin{array}{l}\text { Kidanto HL et al } \\
\text { (34) }\end{array}$ & 2006 & $1999-2003$ & Tanzania & Hospital based & $\begin{array}{l}\text { Retrospective } \\
\text { analysis }\end{array}$ \\
\hline $\begin{array}{l}\text { Mmbaga BT et al } \\
\text { (35) }\end{array}$ & 2012 & $2000-2010$ & Tanzania & Hospital based & $\begin{array}{l}\text { Retrospective } \\
\text { analysis }\end{array}$ \\
\hline $\begin{array}{l}\text { Guidotti RJ et al } \\
\text { (36) }\end{array}$ & 2009 & 2006 & Afghanistan & Hospital based & $\begin{array}{l}\text { Retrospective } \\
\text { analysis }\end{array}$ \\
\hline Carlo WA et al (37) & 2010 & $\begin{array}{l}\text { March 2005-February } \\
2007\end{array}$ & Multiple & Community based & $\begin{array}{l}\text { Comparative cross } \\
\text { sectional }\end{array}$ \\
\hline $\begin{array}{l}\text { Mahande MJ et al } \\
\text { (38) }\end{array}$ & 2013 & $2000-2010$ & Tanzania & Community based & Prospective cohort \\
\hline $\begin{array}{l}\text { Matendo RM et al } \\
\text { S2 (39) }\end{array}$ & 2011 & June-December 2005 & $\begin{array}{l}\text { D. Republic } \\
\text { Congo }\end{array}$ & Community based & Prospective cohort \\
\hline
\end{tabular}




\section{Methodological quality}

Methodological quality of the selected studies was assessed using Evers checklist, which is recommended by Cochrane collaboration (40). Generally, the methodological quality of the studies included in this review was good from observational study perspective. They were well described in terms of the study population, study design, objectives and outcome measures. Furthermore, the authors discussed the strengths and weaknesses of their studies and the statistical tests performed in each primary study were appropriate. The conclusions were drawn from the results. However, nearly half of these studies, being health facility based, might not be representative for the source population in the catchment areas of the primary studies. There was also marked differences in their sample sizes.

\section{Findings of the review}

As Figure 2 shows, the overall OR demonstrated that perinatal mortality was strongly associated with antenatal care $(\mathrm{OR}=3.2 ; 95 \% \mathrm{CI}, 1.03-9.73)$. However, the sensitivity analysis showed the instability of the overall OR; with the exclusion of any one of the studies (20-25), there was no association of perinatal mortality with antenatal care. The odds of perinatal mortality in those babies with their mothers not attending antenatal care were 2.6-27.0 fold higher than those mothers who had antenatal care. But, the heterogeneity testing showed very significant variability among the studies $\left(I^{2}=99 \%\right)$ even with the exclusion of any of the studies.

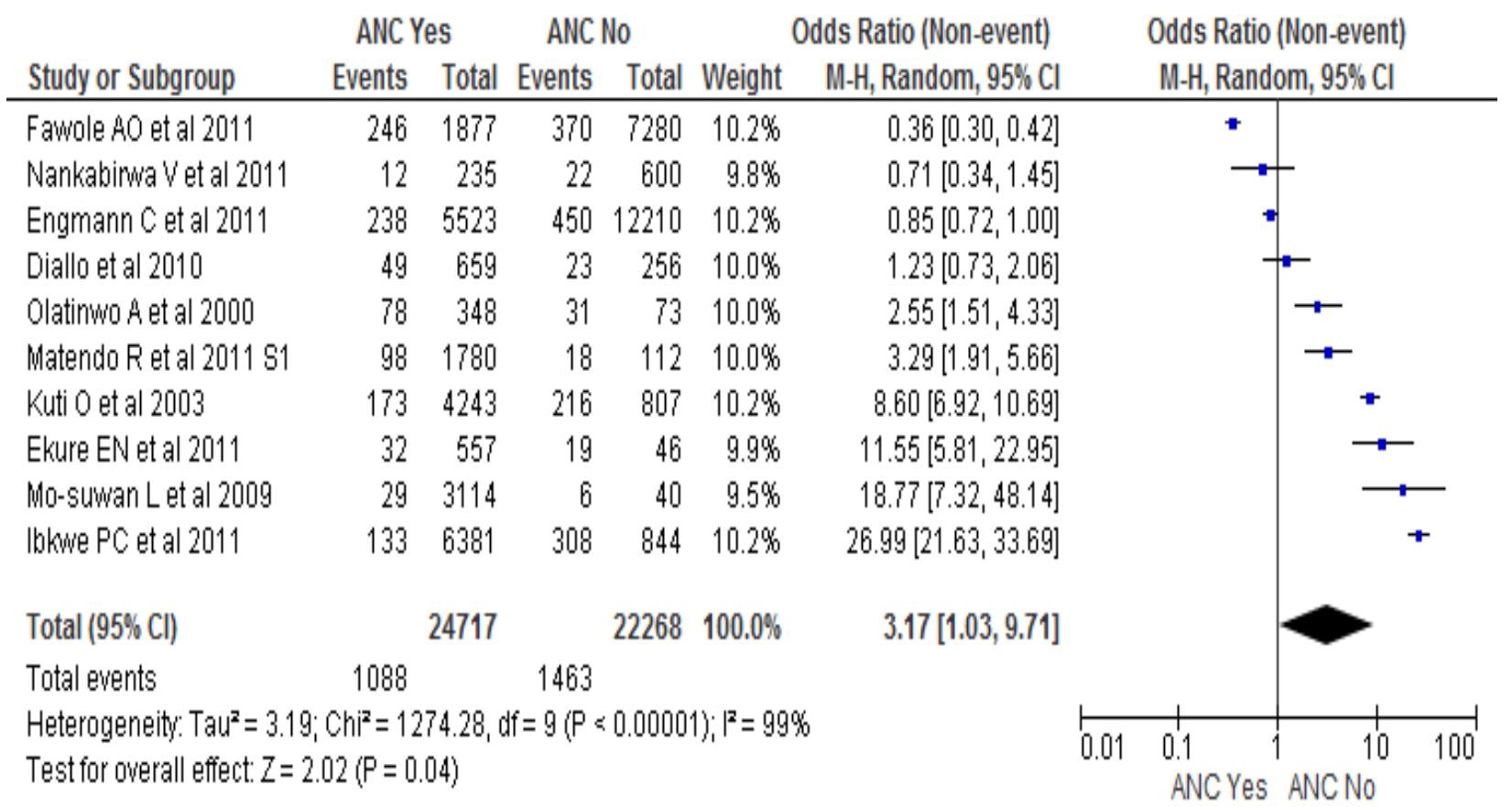

Figure 2: Meta-Analysis of the association of perinatal mortality with antenatal care

As shown in Figure 3, using 32 African countries demographic and health survey (DHS) data, the regression analysis revealed down-going trend lines of stillbirth and neonatal mortality rates in relation to the proportion of antenatal care. The bivariate Pearson correlation coefficient indicated a negative association of antenatal care with stillbirth rate $((\mathrm{r}=-0.4 ; \mathrm{P}=0.01)$ and neonatal mortality rate $(\mathrm{r}=-0.5 ; \mathrm{P}=0.006)$. 


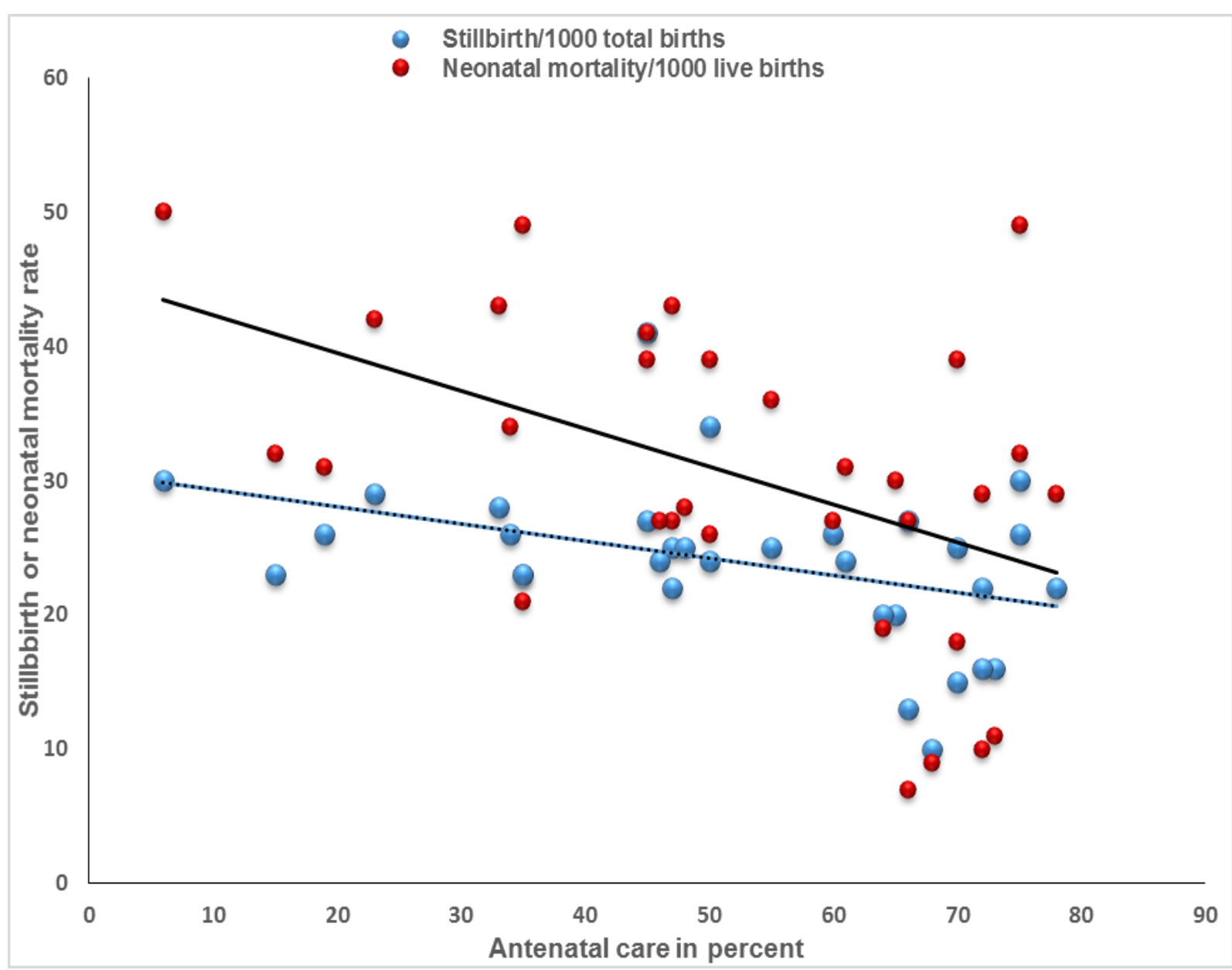

Figure 3: Regression analysis of antenatal care in relation to still birth and neonatal mortality rates using 32 demographic and health survey $(D H S)$ data from Africa. Bivariate Pearson correlation coefficient $(r)=$ - 0.4; $P=0.01$ for stillbirth rate; $r=-0.5 ; P=0.006$

Figure 4 presents the meta-analysis of the association between perinatal mortality and parity. The overall OR has shown that there was about 1.5 -fold increase in perinatal mortality among primigravida women $(\mathrm{OR}=1.5 ; 95 \% \mathrm{CI}, 1.31$ 1.73). There was moderate heterogeneity among included studies $\left(\mathrm{I}^{2}=58 \%\right)$. However, with the exclusion of Pervin $\mathrm{J}$ et al study (32), the heterogeneity became $29 \%$. The OR was not also significantly affected in the sensitivity analysis; with the exclusion of any of the included studies, the OR was swinging between -0.02 and +0.04 . In five studies $(20,22,23,29,31)$, however, there was no statistically significant difference in perinatal mortality between multiparous and primigravid women. 
Odds Ratio

Study or Subgroup

Mo-suwan L et al 2009

Ekure EN et al 2011

Hinderaker 86 et al 2003

Oti 80 et al 2011

Fawole $A 0$ et al 2011

Olatinwo A et al 2000

Kuti 0 et al 2003

Engmann $\mathrm{C}$ et al 2011

Pervin J et al 2012

Diallo et al 2010

Nankabirwa Vet al 2011

$\mathrm{M}-\mathrm{H}$, Random, $95 \% \mathrm{Cl}$

Odds Ratio

M-H, Random, $95 \% \mathrm{Cl}$

Total $(95 \% \mathrm{Cl})$

$0.74[0.35,1.55]$

$0.93[0.50,1.72]$

$1.24[0.75,2.06]$

$1.32[0.89,1.96]$

$1.34[1.14,1.58]$

$1.35[0.76,2.38]$

$1.54[1.24,1.91]$

$1.60[1.37,1.88]$

$1.87[1.67,2.09]$

$1.88[1.08,3.28]$

$2.76[1.38,5.52]$

$1.50[1.31,1.73]$

Total events

Heterogeneity: $\operatorname{Tau}^{2}=0.02 ; \mathrm{Chi}^{2}=23.86, \mathrm{df}=10(\mathrm{P}=0.008) ; \mathrm{I}^{2}=58 \%$

Test for overall effect: $Z=5.74$ ( $P<0.00001$ )

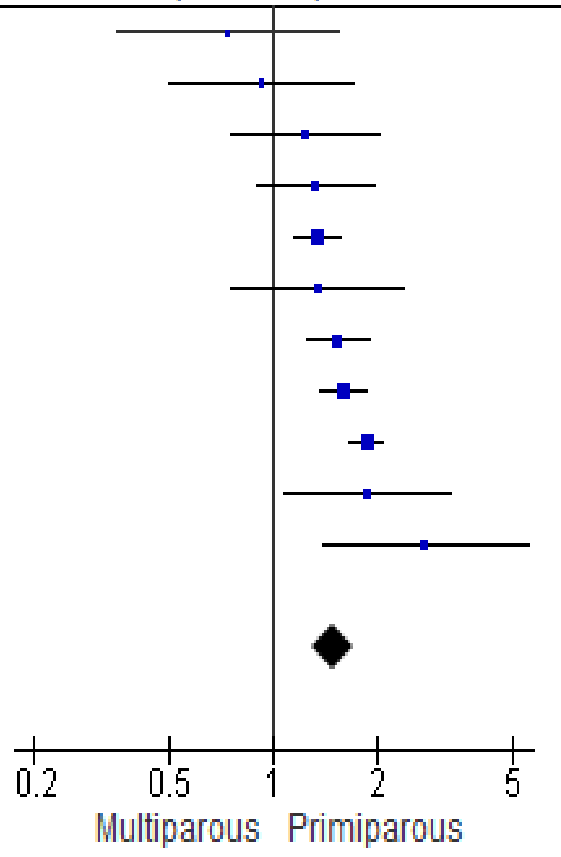

Figure 4: Meta-Analysis of the association of perinatal mortality with parity

In Figure 5, pooled analysis was done for eight studies that assessed the association of perinatal mortality with mode of delivery. Although two studies showed a high perinatal mortality in cesarean delivery, in the overall meta-analysis, there was no increased perinatal mortality in either vaginal or abdominal route mode of delivery. In the sensitivity analysis, the overall OR also remains stable. It should also be noted that, because of few cases in the caesarean delivery, the $95 \%$ CI was very wide.
Odds Ratio

Study or Subgroup

Matendo $R$ et al 201181

Fawole AO et al 2011

Mo-suwan L et al 2009

Ekure EN et al 2011

Guidotti RJ et al 2009

Pervin J et al 2012

Ibkwe $P C$ et al 2011

Lansky $S$ et al 2007

Total $(95 \% \mathrm{Cl})$

Total events

Heterogeneity: Tau $^{2}=0.17 ; \mathrm{Chi}^{2}=101.23, \mathrm{df}=7(\mathrm{P} \leq 0.00001) ; \mathrm{I}^{2}=93 \%$

Test for overall effect: $Z=1.07(P=0.28)$
Odds Ratio $\mathrm{M}-\mathrm{H}$, Random, $95 \% \mathrm{Cl}$

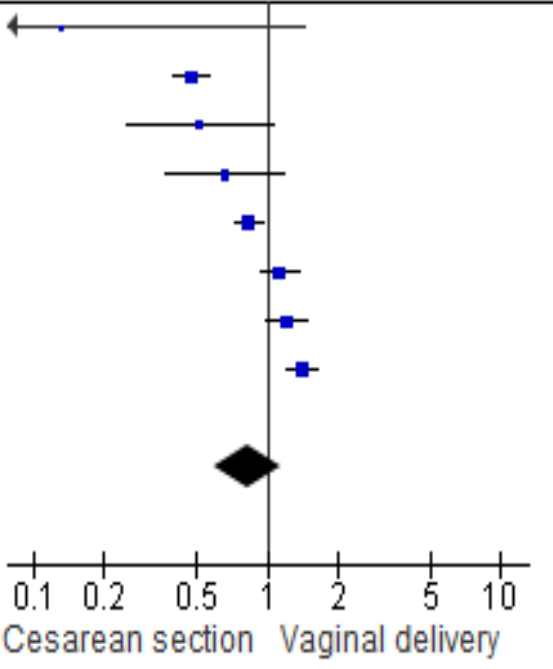

Figure 5: Meta-Analysis of the association of perinatal mortality with mode of delivery 
As shown in Figure 6, the meta-analysis of studies that assessed the association of gestational age with perinatal mortality found that babies who were delivered prematurely had more than 7.9 times higher odds of dying in the perinatal period
$(\mathrm{OR}=7.9 ; 95 \% \mathrm{CI}, 2.02-31.12)$ than babies born after 37 weeks of gestation. But, the heterogeneity testing showed very high variability among the included studies.
Odds Ratio

\begin{tabular}{lr} 
Study or Subgroup & M-H, Random, 95\% Cl \\
\hline Fawole A0 et al 2011 & $3.82[3.23,4.52]$ \\
Mahande MJ et al 2013 & $4.95[3.73,6.57]$ \\
Engmann C et al 2011 & $5.48[4.66,6.44]$ \\
Pewin J et al 2012 & $37.89[33.69,42.62]$ \\
& \\
Total (95\% Cl) & $7.93[2.02,31.12]$ \\
Total events & \\
Heterogeneity: Tau $^{2}=1.94 ; \mathrm{Chi}^{2}=799.85, \mathrm{df}=3(\mathrm{P}<0.00001) ; \mathrm{I}^{2}=100 \%$ \\
Test for overall effect: $\mathrm{Z}=2.97(\mathrm{P}=0.003)$
\end{tabular}

Odds Ratio M-H, Random, $95 \% \mathrm{Cl}$

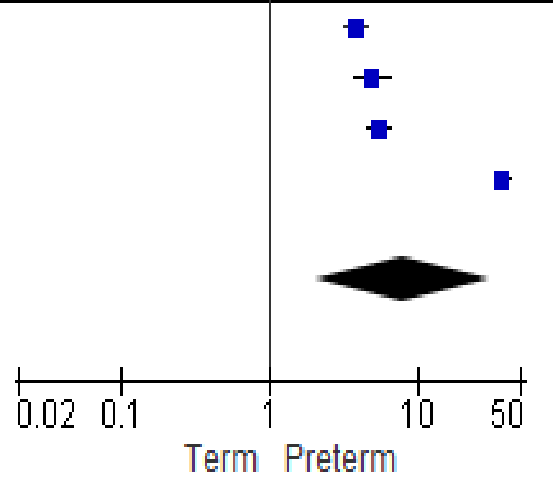

Figure 6: Meta-Analysis of the association of perinatal mortality with gestational age

Similarly, the fetal birth weight was a very strong predictor of perinatal mortality. The odds of perinatal death among babies with low birth weight was about 9.6 fold higher than babies with normal birth weight $(\mathrm{OR}=9.6$; 95\%CI, 6.1215.02) (Figure 7). The finding was consistent in all studies except one (24) which showed more perinatal mortality among babies with birth weight $\geq 2500 \mathrm{gm}$. However, the heterogeneity testing revealed significant variability among the included studies $\left(\mathrm{I}^{2}=99 \%\right)$ and it has remained unchanged with exclusion of any of the studies.

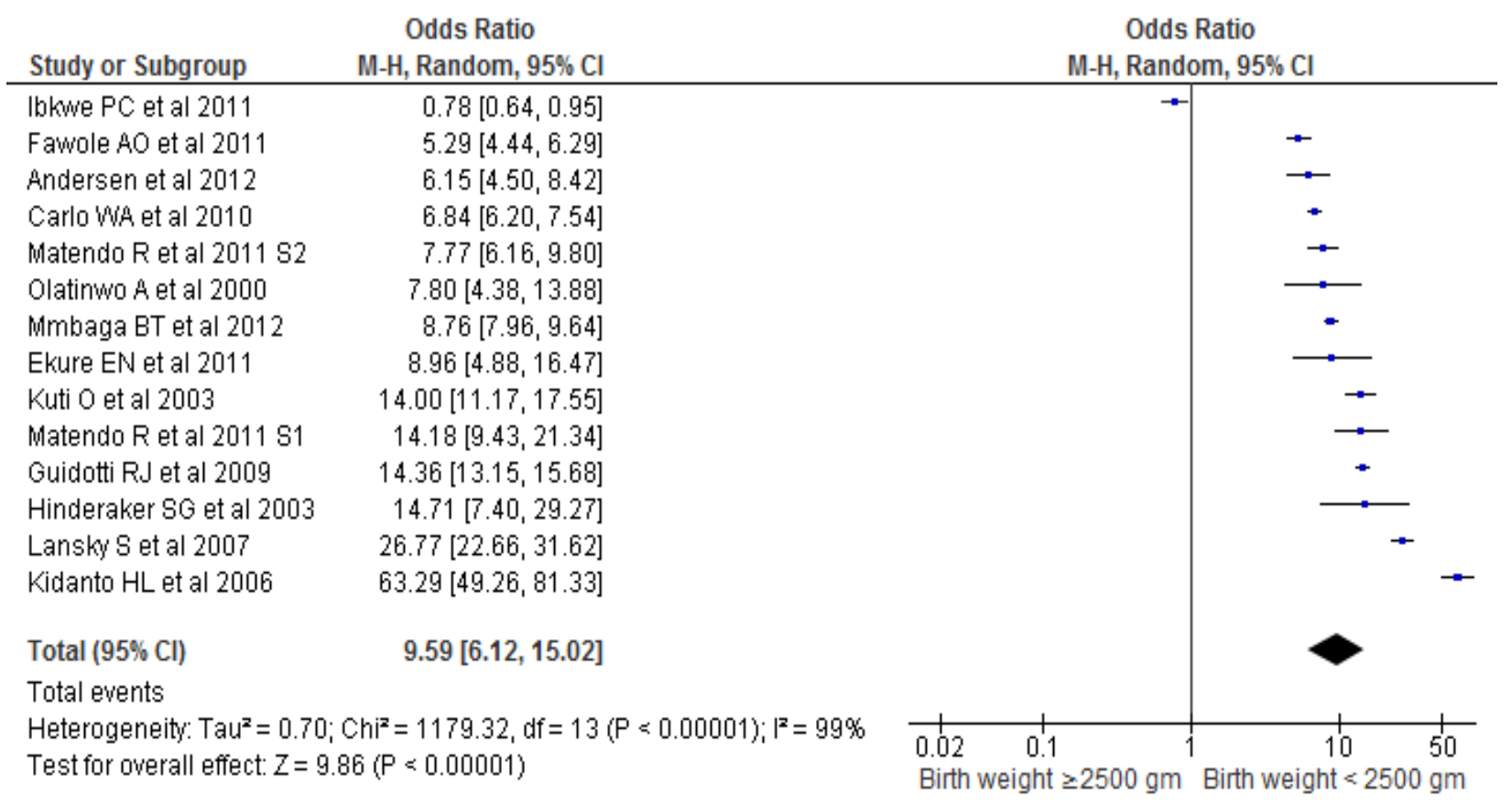

Figure 7: Meta-Analysis of the association of perinatal mortality with fetal birth weight 
Lastly, meta-analysis was done for the association of perinatal mortality by fetal sex (Figure 8). In the overall analysis, there was a weak association of perinatal death with being male baby weak (OR $=1.2 ; 95 \% \mathrm{CI}, 1.07-1.34)$. This is because, in the pooled analysis, being male remained a strong risk factor for perinatal mortality in five studies (23, $28,31,37,39)$, the square of the forest plots continue demonstrating a little bit increased perinatal mortality among male babies. The heterogeneity testing showed significant with moderate variability $\left(\mathrm{I}^{2}=67 \%\right)$ but the sensitivity analysis attested the stability of the overall OR; with exclusion of any of the studies, the odds of perinatal death fluctuated within the range of -0.04 and +0.04 .
Odds Ratio

Study or Subgroup

Ibkwe $\mathrm{PC}$ et al 2011

Habib NA et al 2011

Ekure EN et al 2011

Andersen et al 2012

Carlo WA et al 2010

Engmann $\mathrm{C}$ et al 2011

Matendo $\mathrm{R}$ et al $2011 \mathrm{~S} 1$

Fawole AO et al 2011

Matendo $\mathrm{R}$ et al $2011 \mathrm{~S} 2$

Andargie $G$ et al 2013

Oti 50 et al 2011

Total $(95 \% \mathrm{Cl})$

Total events

Heterogeneity: $\operatorname{Tau}^{2}=0.02 ; \mathrm{Chi}^{2}=30.37, \mathrm{df}=10(\mathrm{P}=0.0007) ; \mathrm{I}^{2}=67 \%$

Test for overall effect: $Z=3.20(P=0.001)$
M-H, Random, $95 \% \mathrm{Cl}$

$0.86[0.71,1.04]$

$0.99[0.84,1.17]$

$1.00[0.56,1.78]$

$1.06[0.87,1.30]$

$1.22[1.12,1.33]$

$1.23[0.98,1.55]$

$1.28[0.88,1.87]$

$1.28[1.10,1.50]$

$1.41[1.13,1.76]$

$1.65[1.06,2.57]$

$1.79[1.32,2.41]$

$1.20[1.07,1.34]$
Odds Ratio

M-H, Random, $95 \% \mathrm{Cl}$

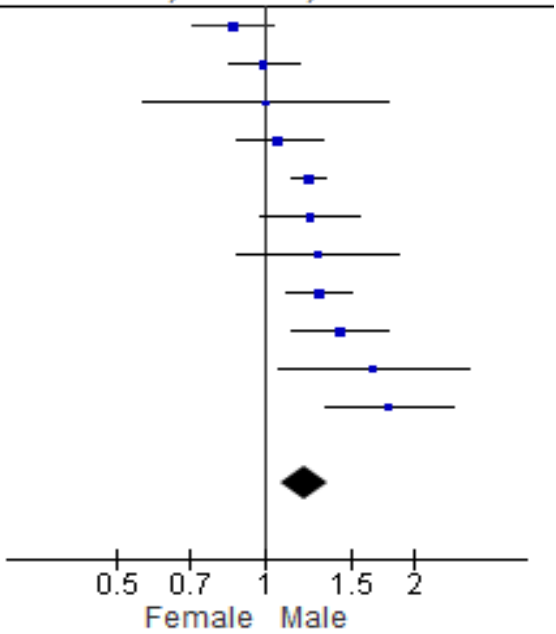

Figure 8: Meta-Analysis of the association of perinatal mortality with fetal sex

In Figure 9, meta-analysis was done to assess the association of perinatal mortality with a skilled person attended delivery by including 8 studies $(16,18,19,21,30,31,37,39)$. Two studies exhibited association of perinatal mortality with a skilled person attended delivery $(21,39)$, and three studies exhibited a strong association of perinatal mortality with a skilled person unattended home delivery $(18,30,37)$. However, the overall OR demonstrated that perinatal mortality was not associated with a skilled person unattended delivery even with the exclusion of one of the included studies during the sensitivity analysis) $(\mathrm{OR}=1.4 ; 95 \% \mathrm{CI}, 0.91-2.15)$. It was also noted that there was a very significant heterogeneity among the studies included $\left(\mathrm{I}^{2}=95 \%\right)$.

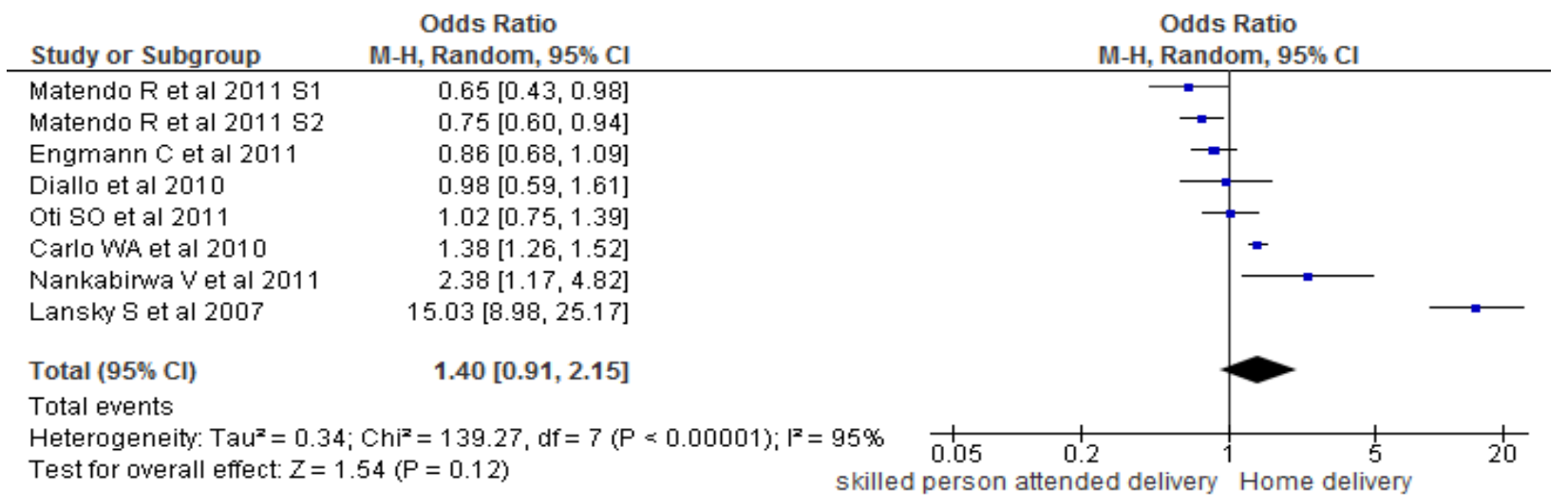

Figure 9: Meta-analysis of perinatal mortality in relation to place of delivery 


\section{DISCUSSION}

Although there were several inconsistent results among primary studies included, the pooled metaanalyses demonstrated the increased risk of perinatal mortality with lack of antenatal care, primigravidity, preterm delivery, low birth weight and male sex. With regard to lack of antenatal care, several other studies also identified it as an important predictor of perinatal mortality $(26,41$ 43). Unlike the reports in the 1980s and 1990s (44, 45), many authors in recent years identified that mothers who had antenatal care were likely to deliver in health facilities and had post natal care, which were again linked to reduction in perinatal mortality $(32,46-48)$ as this meta-analysis showed.

Why attending antenatal care was associated with increased (17) or no change $(16,18,19)$ in perinatal mortality among the included studies might be due to other risk factors not assessed in this meta-analysis like the severe form of obstetric diseases (preeclampsia or eclampsia, major degree antepartum hemorrhage, preterm labor) (48-53), delay in accessing or getting proper obstetric care during labor and delivery (53-56) or due to intrinsic fetal problems (congenital anomalies, malpresentations or intrauterine infections) (51, 56-58). Otherwise, antenatal care was found to be

one of the predictors of health facility based delivery by lowering the barriers between pregnant women and the skilled health personnel $(42,59)$, which is again an important intervention to reduce perinatal mortality $(26,60,61)$. The negative correlation of the proportion of antenatal care with stillbirth and neonatal mortality rates is also strong evidence which demonstrated the importance of antenatal care to reduce the perinatal mortality.

Similarly, this analysis has identified that the association of perinatal mortality with parity was not far from controversy; the overall odds ratio showed an increased risk of perinatal mortality among primigravid women. However, in seven out of eleven studies, there was no statistically significant association of perinatal mortality with parity. The absence of an association of perinatal mortality among primigravid women in the majority of the studies is probably masked or counterbalanced by the increased perinatal deaths among women with high parity, which was also noted in another study (48). Furthermore, the increased utilization of health facility delivery by primigravid women observed in a meta-analysis (61) has probably contributed to the reduction in the perinatal mortality among primigravid women.

Even in some of the included studies $(17,20$, $21,23,29)$, it was observed that the perinatal mortality has a V-shape pattern with regard to parity; low between para two and four, high among primigravida and grand multiparous, which was also the finding in several low income countries $(48,63,64)$. But, in several developed nations, perinatal mortality was not associated with grand and great-grand multiparity (65-68), and the authors argued that grand multiparity is no longer needs to be considered a high-risk obstetric category provided that there is good perinatal care. In this analysis, the overall OR did not demonstrate association of perinatal mortality with the mode of delivery. However, it was noted that in two studies, vaginal delivery was a risk; in another two studies, cesarean delivery was a risk; and in three studies, there was no statistically significant association of perinatal mortality with mode of delivery. Some other studies also showed an association of perinatal deaths with cesarean delivery and abnormal vaginal delivery $(69,70)$.

However, it should be noted that the mode of delivery (either cesarean or abnormal vaginal delivery) may not be directly attributed to the perinatal mortality unless complicated by traumatic manipulation, which is not uncommon in instrumental vaginal delivery (71) and in deeply impacted head extraction during cesarean section (72). This is because; the indication for cesarean or abnormal vaginal delivery (instrumental or breech) in the majority of the cases are usually emergency conditions, commonly due to fetal jeopardy as a result of serious obstetric problems or labor abnormalities $(70,73)$, which have probably significantly contributed to the high perinatal deaths.

In short, in the current study, mode of delivery and skilled person attended delivery were not predictor of perinatal mortality. A comparison of perinatal outcome with mode of delivery (using case control or cohort study method) may sound appropriate in non-emergency conditions like attempting vaginal delivery or offering an elective cesarean section for breech presentation, twin 
pregnancy, scarred uterus, suspected cephalo pelvic disproportion and in condition with exactly unknown risk of vertical infection transmission. The high statistically significant association of perinatal mortality with low birth weight and preterm birth is consistent with several previous studies findings $(50,74-76)$. The significantly low survival of the preterm and low birth weight babies may indicate the poor quality of care in the peripartum period in the primary study areas. WHO stated that experience from developed and low-and middle-income countries has clearly shown the improved survival of low birth weight and preterm babies by providing appropriate care during pregnancy and after birth (76). To improve the survival of low birth weight and preterm babies, WHO has also recommended optimal care in temperature maintenance, adequate feeding, hygienic cord and skin care, and early detection and treatment of infections and respiratory distress syndrome.

On the other hand, why male babies were at higher risk of death during the perinatal period was an unexpected finding. A case control study not included in this analysis also showed a similar finding (50).

This meta-analysis has several limitations. Because of few studies included in this metaanalysis, the conclusions may not reflect the reality in all developing countries. The observed association of perinatal mortality with antenatal care and parity, and the inconsistent reports with regard to mode of delivery remained likely to be confounded by other factors. The significant heterogeneity among the included studies is another limitation. Furthermore, because of the limitation of the meta-analysis software, it was not possible to perform multicategorical independent variables meta-analysis.

In conclusion, the present meta-analysis demonstrated a strong association of perinatal mortality with lack of antenatal care, preterm gestational age, low birth weight, and marginal association with primigravidity and male fetal sex. The implication is that further studies with good control of confounders need to be done in low income countries to verify the conclusions made about the risks of perinatal mortality with regard to parity in developed nations. Similarly, the association of perinatal mortality with mode of delivery and fetal sex needs further investigation.
Above all, the utilization of antenatal care service needs to be strengthened.

\section{ACKNOWLEDGEMENT}

We would like to thank PANE and KMG Ethiopia for the modest financial support granted for this review. We are also grateful to UNFPA Ethiopia for their generous financial support to cover the publication fee.

\section{REFERENCES}

1. Bhutta ZA, Chopra $\mathrm{M}$, Axelson $\mathrm{H}$, et al. Countdown to 2015 decade report (2000-10): taking stock of maternal, newborn, and child survival. Lancet 2010; 375:2032-44.

2. Stanton C, Lawn JE, Rahman H, WilczynskaKetende K, Hill K. Stillbirth rates: delivering estimates in 190 countries. Lancet 2006; 367:1487-94.

3. Rajaratnam JK, Marcus JR, Flaxman AD, et al. Neonatal, post neonatal, childhood, and under-5 mortality for 187 countries, 1970-2010: a systematic analysis of progress towards Millennium Development Goal 4. The Lancet 2010; 375(9730):1988-2008.

4. Black RE, Cousens S, Johnson HL, et al. Global, regional, and national causes of child mortality in 2008: a systematic analysis. The Lancet 2010; 375(9730):1969-1987

5. Lawn JE, Kerber K, Enweronu-Laryea C, Cousens S, Stat DM. 3.6 Million Neonatal Deaths-What Is Progressing and What Is Not? Semin Perinatol 2010; 34:371-386.

6. Lawn JE, Cousens S, Zupan J. 4 million deaths: When? Where? Why? The Lancet 2005; 365 (9462):891 - 900 .

7. World Health Organization's: Neonatal and perinatal mortality, 2004: country, regional and global estimates. Geneva: World Health Organization; 2007

8. Campbell O, Koblinsky M, Taylor P. Off to a rapid start: appraising maternal mortality and services Int J Gynaecol Obstet 1995; 48 (Suppl):S33-S52.

9. Avenant T. Neonatal near miss: a measure of the quality of obstetric care. Best Pract Res Clin Obstet Gynaecol 2009; 23(3):369-74.

10. Velaphi S, Rhoda N. Reducing neonatal deaths in South Africa - are we there yet, and what can be done? SAJCH 2012; 6(3): 67-71. 
11. Simmons LE, Rubens CE, Darmstadt GL, Gravett MG. Preventing preterm birth and neonatal mortality: exploring the epidemiology, causes, and interventions. Semin Perinatol 2010; 34:408-15.

12. Lawn JE, Wilczynska-Ketende K, Cousens SN. Estimating the causes of 4 million neonatal deaths in the year 2000. Int J Epidemiol 2006; 35:706-18.

13. Ishaque S, Yakoob MY, Imdad A, Goldenberg RL, Eisele TP, Bhutta ZA. Effectiveness of interventions to screen and manage infections during pregnancy on reducing stillbirths: a review. BMC Public Health 2011; 11:S3. $\mathrm{http} / / / \mathrm{www}$.biomedcentral.com

14. Watson-Jones D, Weiss HA, Changalucha JM, et al. Adverse birth outcomes in United Republic of Tanzania - impact and prevention of maternal risk factors. Bull World Health Org 2007; 85:918

15. Geelhoed D, Agadzi F, Visser L, et al. Maternal and fetal outcome after severe anemia in pregnancy in rural Ghana. Acta Obstet Gynecol Scand 2006; 85:49-55.

16. Engmann C, Walega P, Aborigo RA, et al. Stillbirths and early neonatal mortality in rural Northern Ghana. Trop Med Int Health 2012; 17(3):272-82.

17. Fawole AO, Shah A, Tongo O, et al. Determinants of perinatal mortality in Nigeria. Int J Gynaecol Obstet 2011; 114(1):37-42.

18. Nankabirwa $\quad \mathrm{V}$, Tumwine JK, Tylleskär T, Nankunda J, Sommerfelt H. Perinatal mortality in eastern Uganda: a community based prospective cohort study. PLoS One 2011; 9; 6(5):e19674.

doi: 10.1371/journal.pone.0019674.

19. Diallo AH, Meda N, Zabsonré E, Sommerfelt $\mathrm{H}$, Cousens $\quad \mathrm{S}$, Tylleskär $\mathrm{T}$ Perinatal mortality in rural Burkina Faso: a prospective community-based cohort study. BMC Pregnancy Childbirth 2010; 10:45. http://www.biomedcentral.com

20. Ekure EN, Ezeaka VC, Iroha E, Egri-Okwaji M. Prospective audit of perinatal mortality among inborn babies in a tertiary health center in Lagos, Nigeria. Niger $J$ Clin Pract 2011; 14(1):88-94.

21. Matendo RM, Engmann CM, Ditekemena JD, et al. Challenge of reducing perinatal mortality in rural Congo: findings of a prospective, population-based study. $J$ Health Popul Nutr 2011; 29(5):532-40 (study 1).
22. Mo-suwan L, Isaranurug S, Chanvitan $\mathrm{P}$, et al. Perinatal death pattern in the four districts of Thailand: findings from the Prospective Cohort Study of Thai Children (PCTC). J Med Assoc Thai 2009; 92(5):660-6.

23. Olatinwo A, Anate A, Alao MO. Determinants of perinatal mortality among breech delivery in a Nigerian teaching Hospital. Sahel Med J 2000; 3 (1): 26-29.

24. Ibekwe PC, Ugboma HU, Onyire N, Muoneke U. Perinatal mortality in Southern Nigeria; less than half a decade to the millennium development goals. Ann Med Health Sci Res 2011; 1(2): 215-222.

25. Kuti O, Orji EO, Ogunlola OI. Analysis of perinatal mortality in a Nigerian teaching Hospital. J Obstet Gynaecol 2003; 23(5): 512514.

26. Feresu SA, Harlow SD, Welch K, Gillespie BW. Incidence of stillbirth and perinatal mortality and their associated factors among women delivering at Harare Maternity Hospital, Zimbabwe: a cross-sectional retrospective analysis. $B M C$ Pregnancy Childbirth 2005; 5:9. http://www.biomedcentral.com.

27. Abu Habib N, Wilcox AJ, Daltveit AK, et al. Birth weight, preterm birth and perinatal mortality: a comparison of black babies in Tanzania and the USA. Acta Obstet Gynecol Scand 2011; 90(10):1100-6.

28. Andargie G, Berhane Y, Worku A, Kebede Y. Predictors of perinatal mortality in rural population of Northwest Ethiopia: a prospective longitudinal study. BMC Public Health 2013; 13:168. http://www.biomedcentral.com

29. Hinderaker SG, Olsen BE, Bergsjø PB, Gasheka $P$, Lie RT, Kvåle G. Perinatal mortality in northern rural Tanzania. $J$ Health Popul Nutr 2003; 21(1):8-17.

30. Lansky S, França E, Kawachi I. Social inequalities in perinatal mortality in Belo Horizonte, Brazil: the role of hospital care. Am J Public Health 2007; 97(5):867-73.

31. Oti SO, Odimegwu C. Perinatal Mortality in Nigeria: Do Place of Delivery and Delivery Assistants Matter? TODEMOJ 2011; 4: 1-10.

32. Pervin J, Moran A, Rahman M, et al. Association of antenatal care with facility delivery and perinatal survival -a populationbased study in Bangladesh. BMC Pregnancy Childbirth 2012; 12:111. 
33. Bjerregaard-Andersen M, Lund N, Jepsen FS, et al. A prospective study of twinning and perinatal mortality in urban Guinea-Bissau. $B M C$ Pregnancy $\quad$ Childbirth 2012; 12:140. http://www.biomedcentral.com/

34. Kidanto HL, Massawe SN, Nystrom L, Lindmark G. Analysis of Perinatal mortality at a teaching hospital in Dar es Salaam, Tanzania, 1999-2003. Afr J Reprod Health 2006; 10(2):7280.

35. Mmbaga BT, Daltveit AK, Lie RT, Olomi R, Mahande MJ, Olola O. Causes of perinatal death at a tertiary care hospital in Northern Tanzania 2000-2010: a registry based study. $B M C$ Pregnancy and Childbirth 2012; 12:139. http://www.biomedcentral.com/.

36. Guidotti RJ, Kandasamy T, Betra AP, et al. Monitoring perinatal outcomes in hospitals in Kabul, Afghanistan: The first step of a quality assurance process. J Matern Fetal Neonatal Med 2009; 22(4): 285-292.

37. Carlo WA, Goudar SS, Jehan I, et al. Newborn Care Training and Perinatal Mortality in Communities in Developing Countries. N Engl J Med 2010; 362(7): 614-623.

38. Mahande MJ, Daltveit AK, Obure J, et al. Recurrence of preterm birth and perinatal mortality in northern Tanzania: registry-based cohort study. Trop Med Int Health 2013; 18(8): 962-967.

39. Matendo RM, Engmann CM, Ditekemena JD, et al. Reduced perinatal mortality following enhanced training of birth attendants in the Democratic Republic of Congo: a timedependent effect. BMC Medicine 2011; 9:93. http://www.biomedcentral.com/ (study 2).

40. The Cochrane collaboration. Cochrane Handbook for Systematic Reviews of Interventions version $5.1 .0 \quad$ (2011). http://handbook.cochrane.org/

41. Emmanuel T, Notion G, Gerald S, Addmore C, Mufuta T, Simukai Z. Determinants of perinatal mortality in Marondera district, Mashonaland East Province of Zimbabwe, 2009: a case control study. Pan Afric Med $J$ 2011; 8:7. http://www.panafrican-med-journal.com/

42. Bloom SS, Lippeveld T, Wypij D. Does antenatal care make a difference to safe delivery? A study in urban Uttar Pradesh, India. Health Policy Plan 1999; 14(1):38-48.

43. Hailu M, Gebremariam A, Alemseged F, Deribe K. Birth Preparedness and Complication Readiness among Pregnant Women in Southern
Ethiopia. PLoS ONE 2011; 6(6): e21432. doi:10.1371.

44. Møller B, Lushino O, Meirik O, Gebre-Medhin M, Lindmark G. A study of antenatal care at village level in rural Tanzania. Int J Gynaecol Obstet 1989; 30: 123-31.

45. Jahn A, Kowalewaski M, Kimatta SS. Obstetric care in southern Tanzania: does it reach those in need? Trop Med Int Health 1998; 3: 926-32.

46. Rahman A, Moran A, Pervin J, et al. Effectiveness of an integrated approach to reduce perinatal mortality: recent experiences from Matlab, Bangladesh. BMC Public Health 2011; 11:914. doi: 10.1186/1471-245811-914.

47. Olamijulo JA, Olaleye O. Perinatal mortality in Lagos University Teaching Hospital: a five year review. Nig Q J Hosp Med 2011; 21(4):255-61.

48. Schmiegelow C, Minja D, Oesterholt M, et al. Factors associated with and causes of perinatal mortality in Northeastern Tanzania. Acta Obstet Gynecol Scand 2012; 91(9):1061-8.

49. Kusiako T, Ronsmans C, Van der Paal L. Perinatal mortality attributable

to complications of childbirth in Matlab, Bangladesh. Bull World Health Organ 2000; 78(5):621-7.

50. Bayou G, Berhan Y. Perinatal mortality and associated risk factors: a case control study. Ethiopian J Health Scie 2012; 22(3): 153-162.

51. Gaym A. Perinatal mortality audit in Jima hospital, South Western Ethiopia, 1990-1999. Ethiop J Health Dev 2000; 14 (3):335-343.

52. Bellad MB, Srividhya K, Ranjit K, Dhaded SM. Factors Associated with Perinatal Mortality: A Descriptive Observational Study. SAFOG 2010; 2(1):49-51.

53. Weiner R, Ronsmans C, Dorman E, Jilo H, Muhoro A, Shulman C. Labor complications remain the most important risk factors for perinatal mortality in rural Kenya. Bull World Health Organ 2003; 81(8):561-6.

54. Hofmeyer GJ, Haws RA, Bergstrom S, et al. Obstetric care in low resource settings: what, who, and how to overcome challenges to scale up? Int J Gynecol Obstet 2008; 107:S21-S46.

55. Wall SN, Lee ACC, Goldenberg R, et al. Reducing Intrapartum-Related Neonatal Deaths in Low- and Middle-Income Countries-What Works? Semin Perinatol 2010; 34:395-407.

56. Korejo R, Bhutta S, Noorani KJ, Bhutta ZA. An audit and trends of perinatal mortality at the 
Jinnah Postgraduate Medical Centre, Karachi. $J$ Pak Med Assoc 2007; 57(4):168-72.

57. Naeye RL, Tafari N, Marboe CC, Judge DM. Causes of perinatal mortality in an African city. Bull World Health Organ 1977; 55(1):63-5.

58. Abudu OO, Uguru V, Olude O. Contribution of congenital malformation to perinatal mortality in Lagos, Nigeria. Int J Gynaecol Obstet 1988; 27(1):63-7.

59. Berhan Y, Berhan A. Antenatal Care as a means of increasing birth in the health facility and reducing maternal mortality: a systematic review. Ethiop J Health Sci 2014; special issue 1.

60. World Health Organization. Neonatal and perinatal mortality: country, regional \& global estimates. Geneva, Switzerland, 2006. Last accessed, Sept 2013: http://apps.who.int/iris/bitstream/

61. Berhan Y, Berhan A. Skilled health personnel attended delivery as a proxy indicator for maternal and perinatal mortality: A systematic review. Ethiop J Health Sci 2014; special issue...

62. Berhan Y, Berhan A. A meta-analysis of sociodemographic factors for women's health facility delivery. Ethiop J Health Sci 2014; special issue 1.

63. Juntunen K, Kirkinen P, Kauppila A. The clinical outcome in pregnancies of grand grand multiparous women. Acta Obstet Gynecol Scand 1997; 76(8):755-9.

64. Al JF. Grandmultiparity: a potential risk factor for adverse pregnancy outcomes. $J$ Reprod Med 2012; 57(1-2):53-7.

65. Toohey JS, Keegan KA Jr, Morgan MA, Francis $J$, Task S, de Veciana $M$. The "dangerous multipara": fact or fiction? Am J Obstet Gynecol 1995; 172 (2 part 1): 683-6.

66. Kumari AS, Badrinath P. Extreme grandmultiparity: is it an obstetric risk factor? Eur J Obstet Gynecol Reprod Biol 2002; 101(1):22-5.

67. Babinszki A, Kerenyi T, Torok O, Grazi V, Lapinski RH, Berkowitz RL. Perinatal outcome in grand and great-grand multiparity: effects of parity on obstetric risk factors. Am J Obstet Gynecol 1999; 181(3):669-74.

68. Goldman GA, Kaplan B, Neri A, Hecht-Resnick R, Harel L, Ovadia J. The grand multipara. Eur J Obstet Gynecol Reprod Biol 1995; 61(2):105-9.

69. Ugwu EO, Obioha KC, Okezie OA, Ugwu AO. A five-year survey of caesarean delivery at a
Nigerian tertiary hospital. Ann Med Health Sci Res 2011; 1(1):77-83.

70. Villar J, Valladares E, Wojdyla D, et al. Caesarean delivery rates and pregnancy outcomes: the 2005 WHO global survey on maternal and perinatal health in Latin America. Lancet 2006; 367(9525):1819-29.

71. Berhan Y, Kassie A. Extracranial hemorrhage in babies admitted to neonatal unit over a 10-year period. Ethiop J Health Dev 2004; 18(3): 190198.

72. Berhan Y, Berhan A. A meta-analysis of reverse breech extraction to deliver a deeply impacted head during cesarean delivery. Int J Gynecol Obstet 2013; 124(2):99-105. http://dx.doi.org/10.1016/j.ijgo.2013.08.014

73. Berhan Y, Abdella A. Emergency obstetrics performance with emphasis on operative delivery outcome: Does it reflect the quality of care. Ethiop J Health Dev 2004; 18(2):96-106.

74. Buekens P, Wilcox AJ, Kiely J, MasuyStroobant G. Birthweight, preterm births and neonatal mortality in Belgium and the United States. Paediatr Perinat Epidemiol 1995; 9:273280.

75. Lau C, Ambalavanan N, Chakraborty H, Wingate MS, Carlo WA. Extremely low birth weight and infant mortality rates in the United States. Pediatrics 2013; 131(5):855-60.

76. World Health Organization. Maternal, newborn, child and adolescent health. Care of the preterm and/or low-birth-weight newborn. http://www.who.int/maternal_child_adolescent/t opics/newborn/care_of_preterm/ 